\title{
Editorial: Connecting People to Their Oceans: Issues and Options for Effective Ocean Literacy
}

\author{
Angel Borja ${ }^{1 *}$, Francesca Santoro ${ }^{2}$, Gail Scowcroft ${ }^{3}$, Stephen Fletcher ${ }^{4}$ and \\ Pierre Strosser ${ }^{5}$ \\ ${ }^{1}$ AZTI, Marine Research Division, Pasaia, Spain, ${ }^{2}$ Intergovernmental Oceanographic Commission, UNESCO, Venice, Italy, \\ ${ }^{3}$ Graduate School of Oceanography, University of Rhode Island, Narragansett, RI, United States, ${ }^{4}$ School of the Environment, \\ Geography and Geosciences, University of Portsmouth, Portsmouth, United Kingdom, ${ }^{5}$ Acteon, Colmar, France
}

Keywords: ocean literacy, ResponSEAble, behavior change, attitude toward oceans, human pressures

\section{Editorial on the Research Topic}

\section{Connecting People to Their Oceans: Issues and Options for Effective Ocean Literacy}

\section{OPEN ACCESS}

Edited and reviewed by: Katherine Dafforn Macquarie University, Australia

${ }^{*}$ Correspondence Angel Borja aborja@azti.es

Specialty section:

This article was submitted to Marine Ecosystem Ecology, a section of the journal

Frontiers in Marine Science

Received: 11 December 2019 Accepted: 30 December 2019 Published: 21 January 2020

Citation:

Borja A, Santoro F, Scowcroft G Fletcher S and Strosser P (2020) Editorial: Connecting People to Their Oceans: Issues and Options for Effective Ocean Literacy. Front. Mar. Sci. 6:837. doi: 10.3389/fmars.2019.00837
While there is a growing understanding of theimportance of marine ecosystems for society (Selig et al., 2019), evidence shows that pressures from human activities on these ecosystems are increasing (Korpinen and Andersen, 2016; Lotze et al., 2018), putting the health of marine ecosystems at risk worldwide (Borja et al., 2016). In particular, Sustainable Blue Economy ambitions are becoming an important component of national socio-economic development strategies (e.g., this is called Blue Growth in Europe; Eikeset et al., 2018). This can result in increasing pressures on marine and coastal ecosystems if this development is not designed and implemented with care. Thus, despite current regulatory framework across the globe (illustrated inter alia by the Oceans Act in the USA or Canada and the Marine Strategy Framework Directive in Europe; Borja et al., 2008), it is likely that this challenging situation will continue into the future (Golden et al., 2017).

All citizens are directly or indirectly connected to the marine environment. Ensuring that everyone gains a better understanding of the importance of the oceans, the human-ocean interactions, and opportunities to act sustainably and reduce human impacts on marine ecosystem is central to global Ocean Literacy (Santoro et al., 2017). The Ocean Literacy movement, initiated over 25 years ago in the USA, has received increasing attention world-wide, particularly in Europe, where significant funding had propelled the movement forward. Ocean Literacy is a challenge for all parts of society: educators and trainers, children and professionals, civil society and scientists, consumers and policy/decision makers (Uyarra and Borja, 2016). It is seen as an essential part of the strategies necessary to change human behaviors and practices that can result in healthier marine ecosystems, while allowing sustainable development opportunities (Gelcich et al., 2014). Ocean Literacy will be a key pillar of the upcoming United Nations Decade of Ocean Science for Sustainable Development (2021-2030; Ryabinin et al., 2019).

Two projects, funded by the European Commission's Horizon 2020 program and implemented between 2015 and 2019, focused on challenges and solutions for more effective ocean literacy. The project ResponSEAble ${ }^{1}$ investigated how to effectively connect people to their seas and help them better understand the complex human-ocean relationship. This research was intended to identify strategies that will encourage people to make responsible, informed decisions, thus becoming "ocean literate." Its sister project SeaChange ${ }^{2}$ explored the way European citizens view

\footnotetext{
${ }^{1}$ https://www.responseable.eu

${ }^{2} \mathrm{https} / / /$ www.seachangeproject.eu/
} 
their relationship with the sea, by empowering them as "Ocean Literate" citizens, to take direct and sustainable action toward healthy seas and ocean, healthy communities, and, ultimately, a healthier planet.

With this in mind, the editors took the view that a Research Topic in Frontiers in Marine Science would be an ideal platform for synthesizing and giving open access to up-to-date research in Ocean Literacy, as developed in the framework of the two EU projects described above and others across the world. This led to the Research Topic presenting a variety of research that addresses issues and options for achieving Ocean Literacy worldwide, which we anticipate will be useful to those involved in the design, implementation, and evaluation of ocean literacy initiatives that target a variety of audiences.

The papers in the Research Topic discuss: (1) practical experiences in Ocean Literacy (formal and informal education for children, training for professionals, tools for raising awareness of consumers, and of investors in the marine sectors), illustrating their effectiveness at catalyzing the transition from "understanding better" to "acting differently" (Barracosa et al.; Fielding et al.; Mogias et al.); (2) the role Ocean Literacy could play through interaction with innovation, regulation, economic incentive, and social norms to support human capital development as a key component of sustainable growth (Fernández Otero et al.); and (3) pre-conditions for effective and increasing Ocean Literacy for different sectors and target groups (Brennan et al.; Chambers et al.). Questions relevant to Ocean Literacy include: Which knowledge (produced by whom) to share and how? (Salazar et al.; Kopke et al.); Who to target and how to effectively reach

\section{REFERENCES}

Borja, A., Bricker, S. B., Dauer, D. M., Demetriades, N. T., Ferreira, J. G., Forbes, A. T., et al. (2008). Overview of integrative tools and methods in assessing ecological integrity in estuarine and coastal systems worldwide. Mar. Pollut. Bull. 56, 1519-1537. doi: 10.1016/j.marpolbul.2008.07.005

Borja, A., Elliott, M., Andersen, J. H., Berg, T., Carstensen, J., Halpern, A.-S., et al. (2016). Overview of integrative assessment of marine systems: the Ecosystem Approach in practice. Front. Mar. Sci. 3:20. doi: 10.3389/fmars.2016.00020

Eikeset, A. M., Mazzarella, A. B., Davíðsdóttir, B., Klinger, D. H., Levin, S. A., Rovenskaya, E., et al. (2018). What is blue growth? The semantics of “Sustainable Development" of marine environments. Mar. Policy 87, 177-179. doi: 10.1016/j.marpol.2017.10.019

Gelcich, S., Buckley, P., Pinnegar, J. K., Chilvers, J., Lorenzoni, I., Terry, G., et al. (2014). Public awareness, concerns, and priorities about anthropogenic impacts on marine environments. Proc. Natl. Acad. Sci. U.S.A. 111, 15042-15047. doi: $10.1073 /$ pnas.1417344111

Golden, J. S., Virdin, J., Nowacek, D., Halpin, P., Bennear, L., and Patil, P. G. (2017). Making sure the blue economy is green. Nat. Ecol. Evol. 1:0017. doi: 10.1038/s41559-016-0017

Korpinen, S., and Andersen, J. (2016). A global review of cumulative pressure and impact assessments in marine environment. Front. Mar. Sci. 3:153. doi: $10.3389 /$ fmars.2016.00153

Lotze, H. K., Guest, H., O’Leary, J., Tuda, A., and Wallace, D. (2018). Public perceptions of marine threats and protection from around the world. Ocean Coast. Manage. 152, 14-22. doi: 10.1016/j.ocecoaman.2017.11.004 those targeted? (Seraphin et al.; Stefanelli-Silva et al.); How to design Ocean Literacy initiatives, including by mobilizing those targeted (e.g., via living lab approaches), to ensure effective Ocean Literacy and pave the way for behavior change? (Ashley et al.; Barracosa et al.; Stoll-Kleemann et al.); What are the knowledge gaps that limit our capacity to design effective Ocean Literacy initiatives, connecting people to the Ocean? (Chambers et al.). As scientists, it is likely you can discover many more questions discussed in this Research Topic.

We thank all contributing authors and are confident that you will enjoy reading these papers on Ocean Literacy. We hope that the papers will support progressive changes to improve understanding of the oceans and seas and their processes, ultimately leading to a healthier ocean.

\section{AUTHOR CONTRIBUTIONS}

All authors listed have made a substantial, direct and intellectual contribution to the work, and approved it for publication.

\section{FUNDING}

This editorial and the work within this Research Topic is a result of ResponSEAble (Sustainable oceans: our collective responsibility, our common interest. Building on real-life knowledge systems for developing interactive and mutual learning media) project, funded by the European Union under the H2020 Framework Programme (grant agreement no. 652643), www.responseable.eu/.

Ryabinin, V., Barbière, J., Haugan, P., Kullenberg, G., Smith, N., McLean, C., et al. (2019). The UN decade of ocean science for sustainable development. Front. Mar. Sci. 6:470. doi: 10.3389/fmars.2019. 00470

Santoro, F., Santin, S., Scowcroft, G., Fauville, G., and Tuddenham, P. (2017). Ocean Literacy for All - A Toolkit. IOC/UNESCO \& UNESCO Venice office Paris (IOC Manuals and Guides, 80 revised in 2018), 136.

Selig, E. R., Hole, D. G., Allison, E. H., Arkema, K. K., McKinnon, M. C., Chu, J., et al. (2019). Mapping global human dependence on marine ecosystems. Conserv. Lett. 12:e12617. doi: 10.1111/conl.12617

Uyarra, M. C., and Borja, Á. (2016). Ocean literacy: a 'new' socio-ecological concept for a sustainable use of the seas. Mar. Pollut. Bull. 104, 1-2. doi: 10.1016/j.marpolbul.2016.02.060

Conflict of Interest: The authors declare that the research was conducted in the absence of any commercial or financial relationships that could be construed as a potential conflict of interest.

Copyright (C) 2020 Borja, Santoro, Scowcroft, Fletcher and Strosser. This is an openaccess article distributed under the terms of the Creative Commons Attribution License (CC BY). The use, distribution or reproduction in other forums is permitted, provided the original author(s) and the copyright owner(s) are credited and that the original publication in this journal is cited, in accordance with accepted academic practice. No use, distribution or reproduction is permitted which does not comply with these terms. 